of the Organization and of its predecessors to December 31, 1964 (List of Publications. Pp. 58. East Melbourne: Commonwealth Scientific and Industrial Research Organization, 1965). The list includes details of handbooks and monographs, journals, bulletins, pamphlets, circulars, annual reports, divisional publications and publications in the Land Research Series and soil publications. A subject index is provided.

\title{
Federation of European Biochemical Societies
}

THe Federation of European Biochemical Societies has created the post of secretary-general and has appointed Prof. W. J. Whelan to this office. The chairman of the Federation for 1965-66 is Prof. K. Zakrzewski. The Federation, founded in 1964, now unites the membership of twenty-one biochemical societies in the European area, and its activities include the arrangement of an annual international moeting, summer schools in advanced research techniques, charter travel to international congresses and, through a twice-yearly bulletin, information on biochemical meetings in Europe. The third Federation meeting will be held in Warsaw during April 4 7, 1966, and will include a symposium on "Properties and Structure of Genetic Elements" and colloquia on "Biochemistry of Blood Platelets" and "Mitochondrial Metabolism". Information on this meeting may be obtained from the Secretariat, Third Federation Meeting, Polskie Towarzystwo Biochemiczne, 16 Freta Street, Warsaw, 40, and on other Federation activities from Prof. W. J. Whelan, Royal Free Hospital School of Medicine, 8 Hunter Street, London, W.C.1.

\section{University News :}

Aberdeen

THE following appointments have been made: Professorships, Dr. H. F. W. Taylor (newly ereated third chair of chemistry); Dr. K. Walton (newly created second chair of geography); Dr. J. R. Symons (newly created second chair of psychology); Dr. J. R. Mallard (newly created chair of medical physics); Senior Lectureships, Ir. J. D. Lambert and Dr. D. R. Wallace (mathematics); Lectureships, Dr. R. Shilton, Dr. L. S. D. Glasser and Dr. J. A. Duffy (chemistry); M. S. Philip (forestry); Research Fellowship, A. L. Fallas (chemistry).

Belfast

Dr. J. C. Browne has been appointed to the chair of computer science. The following lecturers have been appointed: Dr. J. J. Rooney (physical chemistry); Dr. O. M. White (physics); R. Jennings, J. D. Williams, A. S. Bahrani and W. J. Skelton (mechanical engineoring); A. E. Hidden, D. M. Luke, H. R. Marten and K. H. Edwards (electrical engineering).

Bristol

THE following appointments have been made: Reader ships, Dr. A. Keller (physics); Dr. J. F. Nye (experimental physics); Dr. A. F. W. Hughes (zoology); Dr. J. B. Chappell (biochemistry); Dr. R. T. Severn (civil engineering); Lectureships, Dr. N. W. Ashcroft (theoretical physics); Dr. M. Green (organic chemistry); Dr. R. Parikh (pure mathematics); R. G. Morgan (civil engineering).

Cambridge

Mrs. A. Gregory has been elected to the Perrott. Warrick studentship in psychical research at Trinity College.

Edinburgh

THE following lecturers have been appointed: Dr. F. W. Winton and Dr. J. F. Peutherer (bacteriology); Dr. S. S. Brown (clinical chemistry); Dr. D. H. Mills (forestry and natural resources); T. G. I. Hamnett (social anthropology); J. S. D. Ritchie (veterinary pathology); Dr. A. H. Maddy and Dr. A. W. Ewing (zoology).

THe following titles have been conferred: Professor, Dr. R. Miledi (biophysics, in respect of his post at University College); Dr. R. W. Tiffen (applied mathematics, in respect of his post at Birkbeck College); Dr. T. Estermann (mathematics, in respect of his post at University College); Dr. D. R. Wilkie (experimental physiology, in respect of his post at University College); Reader, Dr. T. C. Griffith and Dr. S. Zienau (physics, in respect of their posts at University College); Dr. G. Stephenson (mathematics, in respect of his post at the Imperial College of Science and Technology); Dr. M. Whitear (zoology, in respect of her post at University College); Dr. N. C. Freeman (aerodynamics, in respect of his post at the Imperial College of Science and Technology); Dr. G. G. Meynell (microbiology, in respect of his post at the Lister Institute of Preventive Medicine); Dr. J. H. Calloman, Dr. H. J. Milledge, Dr. J. H. Ridd and Dr. M. L. Tobe (chemistry, in respect of their posts at University College).

DR. W. LEDERMANN, at present reader in mathematics, has been appointed professor of mathematics.

\section{Announcements}

Dr. B. R. NiJHAWAN, director of the National Metallurgical Laboratory, Jamshedpur, India, has been elected president of the Indian Institute of Metals for the year 1965-66.

THE tenth Congrès Européen d'Hématologie will be held in Strasbourg during August 23-28. Further information can be obtained from Dr. J. Lewin, Centre de Transfusion Sanguine, 10 rue Spielmann, Strasbourg.

THE ninth international conference on the "Biochemistry of Lipids" will be held at Noordwijk during September 5-9. Further information can be obtained from Dr. J. Boldingh, Unilever Research Laboratorium, Mercatorweg 2, Vlaardingen, Holland.

The fifth Western National Meeting of the American Geophysical Union will be held in Dallas, Texas, during September 1-3. Further information can be obtained from Dr. J. C. Harrison, Hughes Research Laboratories, 3011 Malibu Canyon Road, Malibu, California.

Meetings of Commission 3 and Sub-Commissions $6 b$ and $6 c$ of the International Institute of Refrigeration will be held in Prague during August 31-September 9. Further information can be obtained from the Secretary, International Institute of Refrigeration, 177 Boulevard Malesherbes, Paris, 17.

The twentieth annual meeting of the Society of General Physiologists will be held at the Marine Biological Laboratory, Woods Hole, Massachusetts, during September 1-4. The programme will include a symposium on "The Specificity of Cell Surfaces". Further information can be obtained from Roger Milkman, Department of Zoology, Syracuse University, Syracuse, New York 13210.

THE seventh congress of the International Union of Game Biologists will be held in Belgrede and Ljubljana during September 5-11. The programme will include two symposia on "Chemical Products and Techniques used by Man and their Effects on Wild Life" and "Damage to Agricultural and Forest Crops caused by Gamo". Furthor information can be obtained from Prof. S. Valentincic, Gerbiceva 60, Ljubljana.

Corrigendum. In the article entitled "The Auckland Islands" (Nature, 203, 26; 1964) it was stated that the expedition referred to in the article was from the Australian Museum. It was, in fact, dispatched by the New Zealand Department of Scientific and Industrial Research and the Dominion Museum, Wellington, New Zealand. 